\title{
Chitosan/Hydroxyapatite/ $\mathrm{Fe}_{3} \mathrm{O}_{4}$ Magnetic Composite for
}

\section{Metal-Complex Dye AY220 Removal: Recyclable}

\section{Metal-Promoted Fenton-like Degradation}

Pan Hou ${ }^{1}$, Chaoting Shi ${ }^{1}$, Lan $\mathrm{Wu}^{1}{ }^{1}$, Xiandeng $\mathrm{Hou}^{1,2} *$

${ }^{1}$ Analytical \& Testing Center, ${ }^{2}$ College of Chemistry, Sichuan University, Chengdu

Sichuan 610064, China

Corresponding authors' emails: wulan@scu.edu.cn; houxd@scu.edu.cn 


\section{Abstract}

Cross-linked Chitosan (CS) loaded with iron species has been widely used as heterogeneous Fenton catalysts for organic contaminants removal. In comparison with raw-CS based Fenton catalysts, it exhibited an improved degradation efficiency due to the stabilization of cross-linking agents. With cross-linking, however, most reactive sites of CS were occupied by cross-linking agents, making its capability decreased sharply for adsorbing the released metal ions from metal-complex dye degradation. In this work, in order to efficiently adsorb the released metal ions from metal-complex dyes and avoid a secondary pollution, a new CS-based heterogeneous Fenton catalyst (Chitosan/Hydroxyapatite $/ \mathrm{Fe}_{3} \mathrm{O}_{4}$ magnetic composite) was developed for AY220 (a model of metal-complex dyes) removal. Hydroxyapatite (HA), a well-known biocompatible material with strong ability for metal ions adsorption, was introduced to combine with $\mathrm{CS}$ for $\mathrm{Fe}_{3} \mathrm{O}_{4}$ loading. The total removal efficiency of AY220 by the magnetic composite can reach as high as $95.0 \%$, and the degradation efficiency of AY220 was greatly enhanced compared with a raw-CS based catalyst and bare $\mathrm{Fe}_{3} \mathrm{O}_{4}$. Meanwhile, the composite can efficiently adsorb $\mathrm{Co}^{2+}$ released from AY220 degradation, which can further promote the degradation of AY220. After five recyclable runs of the composite, the degradation efficiency of AY220 increased from $25.1 \%$ to $45.6 \%$, demonstrating its potential usefulness in recyclable degradation of metal-complex dyes.

Keywords: Chitosan, hydroxyapatite, $\mathrm{Fe}_{3} \mathrm{O}_{4}$, magnetic composite, metal-complex dye, Fenton reaction, dye degradation, dye removal. 


\section{Introduction}

Metal-complex dyes as an important branch of dye industries have been widely used in wool and polyamide dyeing for their excellent color-fixing abilities, high glossiness and good acid or heat resistance properties [1]. Besides aromatic rings, they also contain toxic complex ions (such as $\mathrm{Co}^{2+}$ or $\mathrm{Cr}^{3+}$ ) compared with other commercially available azo-dyes, which further increase their toxicity $[2,3]$, however. Accordingly, to protect the aquatic and ecological system from contamination, the efforts aimed at effectively eliminating them from the waste water before discharging into the environment are truly appealing.

The currently used methods for metal complex dyes removal mainly include adsorption, electro-coagulation and degradation [4-7]. Among them, adsorption has gained a great attention for its low cost and ease of operation. However, without proper treatment or disposal, the adsorbed organic pollutants may cause a secondary pollution. An efficient way to solve this problem is to degrade them into $\mathrm{C}$ and $\mathrm{N}$ compounds without obvious toxicity. Various degradation methods have been employed for metal-complex dyes removal from aqueous solutions, such as electrochemical treatment [4], biochemical disposal [6] and photo Fenton reaction [8]. But the characteristics of time- and energy-consuming and unrecyclable use limit their practical applications. Moreover, the released metal-complex ions during the above degradation processes may also cause a secondary pollution. Therefore, developing alternative ways of time- and energy-saving, recyclable using, and capable of 
adsorbing metal ions to overcome the above drawbacks is truly imperative.

Nowadays, heterogeneous Fenton reaction (iron-based compounds as the reaction catalyst, and without external energy) as an important modification form of classical homogeneous Fenton reaction ( homogeneous solution of iron ions as the reaction catalyst) has been intensively studied for their unique advantages of less ion loss, a wider $\mathrm{pH}$ range than those of classical Fenton reactions, and a variety of heterogeneous catalysts [9-12] have been developed. Among them, loading iron species onto solid supporters is a promising way to form heterogeneous catalysts [13-15].

Chitosan (CS), a linear natural polysaccharide obtained from full or partial deacetylation of chitin, has attracted a great interest as a solid supporter to load iron species due to its resource abundance, environmental friendliness, and excellent abilities for bonding metal ions [16-18]. However, raw CS cannot stand durative attack of $\bullet \mathrm{OH}$ and is lack of enough mechanic strength, thus affecting its degradation efficiency [19]. Glutaraldehyde (GLA) has been then used as a cross-linking agent to stabilize CS, and thus cross-linked CS-based catalysts have been developed with improved degradation efficiency of organic contaminants $[20,21]$. But these catalysts are not able to efficiently adsorb the released metal ions from dye degradation, since the amine groups (main adsorption sites for metal ions adsorption) of CS have almost been occupied by GLA or loaded iron species. Therefore, finding another material with metal ion adsorption abilities to combine with CS as the supporter is significant to make this CS-based catalyst useful for metal-complex dye degradation. 
Immobilizing CS on rigid inorganic materials $[22,23]$ has been reported to be beneficial for its stabilizing and improving its mechanical strength and adsorption efficiency. Among various inorganic materials, hydroxyapatite $\left[\mathrm{Ca}_{10}\left(\mathrm{PO}_{4}\right)_{6}(\mathrm{OH})_{2}, \mathrm{HA}\right]$ has been anchored with CS to improve its stability and mechanical strength, and the as-received CS/HA composite behaved excellent in dye and metal ion removal [24, 25].

In this work, in order to efficiently adsorb the released metal ions from metal-complex dyes degradation and avoid a secondary pollution, a new CS-based heterogeneous Fenton catalyst (Chitosan/Hydroxyapatite/ $\mathrm{Fe}_{3} \mathrm{O}_{4}$ magnetic composite) was developed for AY220 (model dye of metal-complex dyes) removal. Hydroxyapatite (HA, a well-known biocompatible material with strong ability for metal ions adsorption) was introduced to combine with $\mathrm{CS}$ for $\mathrm{Fe}_{3} \mathrm{O}_{4}$ loading. The removal efficiency of AY220 by the magnetic composite can reach as high as $95.0 \%$, and the degradation efficiency of AY220 was also greatly enhanced compared with raw-CS based catalyst or bare $\mathrm{Fe}_{3} \mathrm{O}_{4}$. Meanwhile, the composite also can efficiently adsorb $\mathrm{Co}^{2+}$ released from AY220 degradation, which greatly promoted the degradation of AY220, demonstrating its potential usefulness in recyclable degradation of metal-complex dyes.

\section{Experiment}

\subsection{Chemicals and materials}

All reagents used in the experiment were analytical grade without further 
purification. Hydrochloric acid, calcium nitrate $\left(\mathrm{Ca}\left(\mathrm{NO}_{3}\right)_{2} \cdot 4 \mathrm{H}_{2} \mathrm{O}\right)$, ferric chloride $\left(\mathrm{FeCl}_{3} \cdot 6 \mathrm{H}_{2} \mathrm{O}\right), 30 \%$ (w/w) hydrogen peroxide were purchased from Kelong Chemical Industry Corporation (Chengdu, China). Chitosan, acetate, ammonium phosphatedi basic, sodium hydroxide, and ammonia solution $25-28 \%(\mathrm{w} / \mathrm{w})$ were obtained from Aladdin Industrial Corporation (Shanghai, China). Iron chloride tetrahydrate $\left(\mathrm{FeCl}_{2} \cdot 4 \mathrm{H}_{2} \mathrm{O}\right)$ was from Tianjin Damao Chemical Reagent Corporation (Tianjin, China). Acid yellow 220 (AY220) was supplied by a textile factory in Hangzhou, China. All solutions were prepared with high-purity water.

\subsection{Preparation and characterization of $\mathrm{CS} / \mathrm{HA} / \mathrm{Fe}_{3} \mathrm{O}_{4}$}

$\mathrm{CS} / \mathrm{HA} / \mathrm{Fe}_{3} \mathrm{O}_{4}$ composite was synthesized via co-precipitation method. Firstly, a certain amount of CS was dissolved in $2 \%$ acetic acid solution by stirring in a four-necked flask. $30 \mathrm{~min}$ later, $\mathrm{Ca}\left(\mathrm{NO}_{3}\right)_{2} \cdot 4 \mathrm{H}_{2} \mathrm{O}$ solution was slowly poured into the flask with continuous stirring. Before the mixed solution of $\mathrm{FeCl}_{2}$ and $\mathrm{FeCl}_{3}$ with the molar ratio of 1:2 was added into the flask, the $\mathrm{pH}$ was adjusted to 1 with hydrochloric solution $\left(0.1 \mathrm{~mol} \cdot \mathrm{L}^{-1}\right)$ to prevent $\mathrm{Fe}\left(\mathrm{CH}_{3} \mathrm{COO}\right)_{3}$ and $\mathrm{FePO}_{4}$ from precipitating. The flask was then put in a $80{ }^{\circ} \mathrm{C}$ oil bath under $\mathrm{N}_{2}$ protection. Meanwhile, $\left(\mathrm{NH}_{4}\right)_{2} \mathrm{HPO}_{4}$ and $\mathrm{NH}_{3} \cdot \mathrm{H}_{2} \mathrm{O}$ solution was dropped in simultaneously until the $\mathrm{pH}$ maintained above 10 with vigorous stirring for another $3 \mathrm{~h}$. After cooled down to the room temperature and aged overnight with air cut off, the obtained precipitate isolated by a permanent magnet was washed repeatedly with deionized water and methanol till the $\mathrm{pH}$ of the filtrate close to 7 . Finally, the as-received $\mathrm{CS} / \mathrm{HA} / \mathrm{Fe}_{3} \mathrm{O}_{4}$ composite was dried in a vacuum oven at $40{ }^{\circ} \mathrm{C}$ for $48 \mathrm{~h}$. A series of $\mathrm{CS} / \mathrm{HA} / \mathrm{Fe}_{3} \mathrm{O}_{4}$ 
composites with $20 \%, 33.3 \%, 40 \%, 50 \%$ and $60 \% \mathrm{Fe}_{3} \mathrm{O}_{4}$ contents were synthesized, and the usage of the raw materials was summarized in Table S1.

The phase structure of the $\mathrm{CS} / \mathrm{HA} / \mathrm{Fe}_{3} \mathrm{O}_{4}$ composite was determined by $\mathrm{X}$ 'Pert Pro MPD diffractometer (Philips, Netherlands). Elemental characterization on the surface of the composites was investigated by EDXS (X-Max 51-XMX0019, Oxford Instruments, UK). The dye concentration was determined by a UV-Vis spectrophotometer (UV-1750, Shimadzu, Japan). An inductively coupled plasma optical emission spectrometer (ICP-OES) (ARCOS FHS12, SPECTRO Analytical Instruments $\mathrm{GmbH}$, Germany) was used for cobalt quantification. The particle size was measured by dynamic light scattering (ZEN 3090, Malvern Instrument Ltd., UK). Hysteresis loops were recorded at the room temperature with a JDAW-2000D vibrating sample magnetometer (VSM, Jilin University, China).

\subsection{Adsorption experiments}

\subsubsection{AY220 adsorption}

The adsorption studies were performed with batch equilibration method. $30 \mathrm{mg}$ catalyst was added into a conical flask containing $20 \mathrm{~mL}$ AY220 solution (initial concentration: $500 \mathrm{mg} \mathrm{L}^{-1}$ ) at $25^{\circ} \mathrm{C}$ and reacted with mechanical shaking. For kinetics studies, the concentration of AY220 in the supernatants after different time intervals was determined by the UV-Vis spectrophotometer at $435 \mathrm{~nm}$. Adsorption isotherm experiment was carried out at dark condition. The catalyst was added into the solution of AY220 with different initial concentration ( $\left.100-1500 \mathrm{mg} \mathrm{L}^{-1}\right)$ and shaken for $12 \mathrm{~h}$ to ensure the adsorption equilibrium. Then the equilibrium concentration of AY220 in 
the aqueous phase was measured. The AY220 adsorption removal efficiency $R_{a}$, and equilibrium adsorption capacity $\mathrm{q}_{\mathrm{e}}\left(\mathrm{mg} \mathrm{g}^{-1}\right)$ were calculated as:

$$
\begin{gathered}
R_{a}=\frac{\left(c_{0}-c_{e}\right)}{c_{0}} \times 100 \% \\
q_{e}=\frac{\left(c_{0}-c_{e}\right) V}{M_{S}}
\end{gathered}
$$

where $\mathrm{C}_{0}$ and $\mathrm{C}_{\mathrm{e}}\left(\mathrm{mg} \mathrm{L}^{-1}\right)$ is the initial and equilibrium concentration of AY220 in solution, respectively, V (mL) is the volume of AY220 solution, and Ms ( $\mathrm{g}$ ) is the dosage of the catalyst.

\subsection{2. $\mathrm{Co}^{2+}$ adsorption}

$\mathrm{Co}^{2+}$ adsorption was also performed with batch equilibration method. $30 \mathrm{mg}$ of the catalyst was added into a conical flask containing $\mathrm{CoCl}_{2}$ solution with different initial concentrations $\left(5,10,20,30,40\right.$, and $\left.50 \mathrm{mg} \mathrm{L}^{-1}\right)$ at $25^{\circ} \mathrm{C}$ and reacted for 4 hours with mechanical shaking. After that, the $\mathrm{Co}^{2+}$ concentration in the supernatant was determination by ICP-OES as the concentration after reaction. The adsorption amount of $\mathrm{Co}^{2+}$ by $\mathrm{CS} / \mathrm{HA} / \mathrm{Fe}_{3} \mathrm{O}_{4}$ can thus be obtained according to equation (3).

$$
m_{C o}=\left(c_{0}-c_{t}\right) V
$$

where $\mathrm{C}_{0}$ and $\mathrm{C}_{\mathrm{t}}\left(\mathrm{mg} \mathrm{L}^{-1}\right)$ is the concentration of $\mathrm{Co}^{2+}$ in solution before and after reaction, respectively, $\mathrm{V}(\mathrm{mL})$ is the volume of AY220 solution, and $\mathrm{m}_{\mathrm{Co}}(\mathrm{g})$ is the adsorption amount of $\mathrm{Co}^{2+}$ after reacting for $4 \mathrm{~h}$.

\subsection{Degradation experiments}

\subsubsection{AY220 degradation by $\mathrm{CS} / \mathrm{HA} / \mathrm{Fe}_{3} \mathrm{O}_{4}$}

To examine the total removal efficiency and degradation efficiency of AY220 by 
the catalyst, a certain amount of $\mathrm{H}_{2} \mathrm{O}_{2}$ (w/w: 30\%) was added into $20 \mathrm{~mL}$ AY220 solution (initial concentration: $500 \mathrm{mg} \mathrm{L}^{-1}$ ) containing $30 \mathrm{mg}$ of the catalyst to react, and the supernatant and the catalyst was then collected after a given time interval by a permanent magnet, respectively. The obtained catalyst was then rinsed in $20 \mathrm{~mL}$ $\mathrm{NaOH}$ solution for $1 \mathrm{~h}\left(0.1 \mathrm{~mol} \mathrm{~L}^{-1}\right.$, extraction yield: $\left.94.2 \%\right)$ to elute the absorbed AY220. Meanwhile, the AY220 concentration in the supernatant (denoted as $C_{t}$ ) and that absorbed by the catalyst (denoted as $C_{a t}$ ) after reacting for a given time were all determined with the UV-Vis spectrophotometer. Based on the above process, the total removal efficiency and degradation efficiency of AY220 by the catalyst can thus be calculated as:

$$
\begin{gathered}
R=\frac{\left(c_{0}-c_{t}\right)}{c_{0}} \times 100 \% \\
R_{d}=\frac{c_{0}-\left(c_{t}+c_{a t}\right)}{c_{0}} \times 100 \%
\end{gathered}
$$

where $R$ and $R_{d}$ is the total removal efficiency and degradation efficiency of AY220 by the catalyst, respectively. $C_{0}$ is the initial concentration of AY220, $C_{t}$ and $\mathrm{C}_{\mathrm{at}}$ is the AY220 concentration in the supernatant and absorbed by the catalyst after a given time interval, respectively.

\subsubsection{AY220 degradation by recyclable used $\mathrm{CS} / \mathrm{HA} / \mathrm{Fe}_{3} \mathrm{O}_{4}$}

After the catalyst was used for AY220 removal for the first time, it was then eluted and washed with $\mathrm{NaOH}$ solution and deionized water successively till the $\mathrm{pH}$ close to 7 for its recyclable use. The experimental details, as well as the calculation of the total removal efficiency and degradation efficiency are all the same as presented in 
2.4.3. AY220 degradation by $\mathrm{CS} / \mathrm{HA} / \mathrm{Fe}_{3} \mathrm{O}_{4}$ with adsorbed $\mathrm{Co}^{2+}$ on its surface and equivalent $\mathrm{Co}^{2+}$ in solution

The catalyst with adsorbed $\mathrm{Co}^{2+}$ on its surface (obtained from 2.3.2) was used for AY220 removal after washed by deionized water. For comparison, the catalyst without adsorbed $\mathrm{Co}^{2+}$ was then added to AY220 solution containing equal amount of $\mathrm{Co}^{2+}$ as that of being adsorbed (the adsorbed amount of $\mathrm{Co}^{2+}$ calculated from equation 3) to remove AY220. Both the experimental details were the same as 2.4.1, and the AY220 degradation efficiency was also calculated according to Equation (5).

\section{Results and discussion}

\subsection{Characterization of the catalyst}

Fig. 1 gives the XRD patterns of $\mathrm{CS}, \mathrm{HA}, \mathrm{Fe}_{3} \mathrm{O}_{4}$ and $\mathrm{CS} / \mathrm{HA} / \mathrm{Fe}_{3} \mathrm{O}_{4}$ composite. A broad peak assigned to chitosan around $20^{\circ}$ (Fig.1b) almost disappeared in the XRD pattern of $\mathrm{CS} / \mathrm{HA} / \mathrm{Fe}_{3} \mathrm{O}_{4}$ (Fig.1a), indicating that the intramolecular hydrogen bonds of $\mathrm{CS}$ between $-\mathrm{NH}_{2}$ and $-\mathrm{OH}$ groups were broken or destroyed by the inorganic phases of $\mathrm{HA}$ and $\mathrm{Fe}_{3} \mathrm{O}_{4}[26]$. The addition of $\mathrm{HA}$ and $\mathrm{Fe}_{3} \mathrm{O}_{4}$ affected the crystallinity of CS and made its XRD peak become extremely weak as shown in Fig.1a. All the characteristic peaks of HA (denoted as "1" in Fig.1c) and $\mathrm{Fe}_{3} \mathrm{O}_{4}$ (denoted as "2" in Fig.1d) can be seen in the composite material, and were all broadened in the composite (Fig.1a), further confirming the strong interaction between inorganic phases and CS of the composite [27]. 


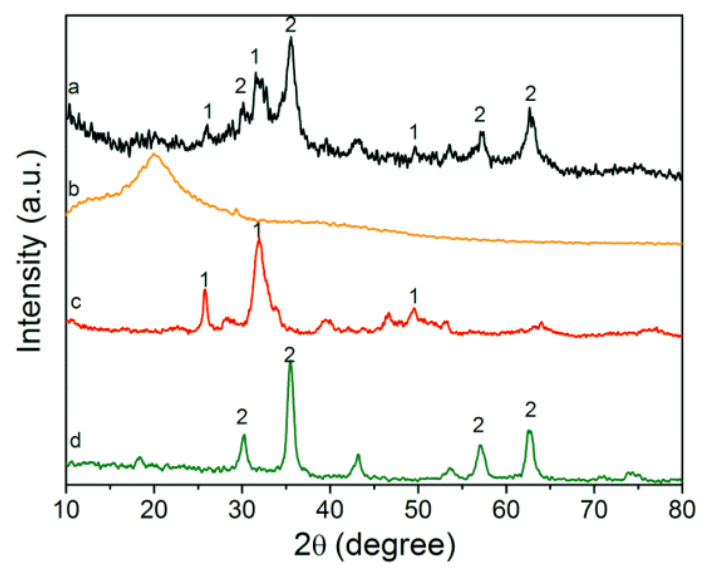

Fig.1. X-ray diffraction patterns of CS/HA/Fe3O4(a), CS(b), $\mathrm{HA}(\mathrm{c})$, and $\mathrm{Fe} 3 \mathrm{O} 4$ (d) and main peaks of $\mathrm{HA}$ (denoted as 1), and $\mathrm{Fe}_{3} \mathrm{O}_{4}$ (denoted as 2).

The magnetic hysteresis loops of $\mathrm{Fe}_{3} \mathrm{O}_{4}$ and $\mathrm{CS} / \mathrm{HA} / \mathrm{Fe}_{3} \mathrm{O}_{4}$ composite measured at the room temperature are shown in Fig. 2. The saturation magnetization (Ms) is found to be $60.05,14.82$ emu $\mathrm{g}^{-1}$ for $\mathrm{Fe}_{3} \mathrm{O}_{4}$ and $\mathrm{CS} / \mathrm{HA} / \mathrm{Fe}_{3} \mathrm{O}_{4}$ composite, respectively. Although the saturation magnetization value of the $\mathrm{CS} / \mathrm{HA} / \mathrm{Fe}_{3} \mathrm{O}_{4}$ composite is lower than that of $\mathrm{Fe}_{3} \mathrm{O}_{4}$, it could also be rapidly separated from its water dispersion by an external magnet in several seconds, as displayed in the upper inset of Fig. 2. The reason of the decreased saturation magnetization value for the $\mathrm{CS} / \mathrm{HA} / \mathrm{Fe}_{3} \mathrm{O}_{4}$ composite can be ascribed to the presence of non-magnetic chitosan and hydroxyapatite. The above results indicated that $\mathrm{CS} / \mathrm{HA} / \mathrm{Fe}_{3} \mathrm{O}_{4}$ composite exhibited enough magnetic response to meet the need of magnetic separation. 


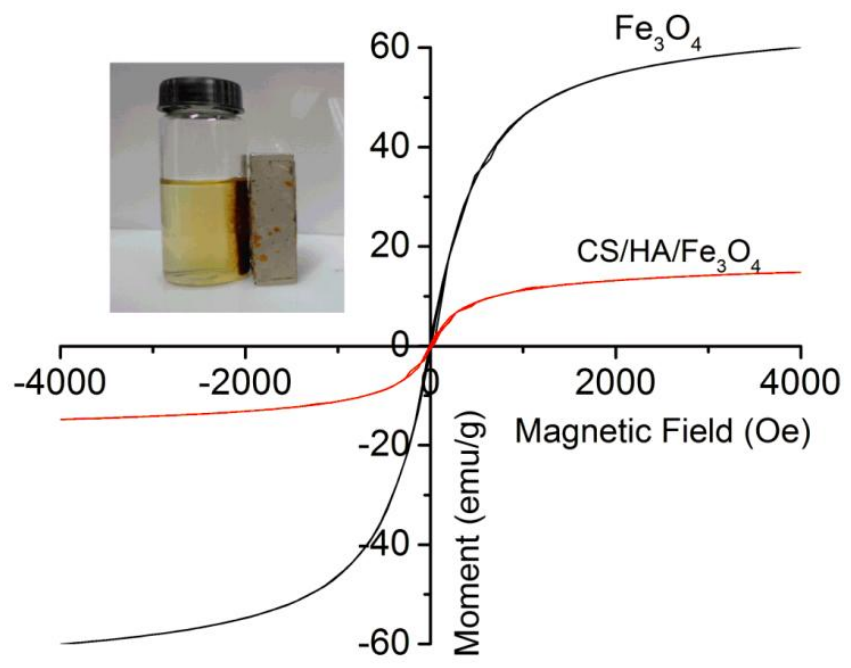

Fig.2. Magnetic hysteresis loops of $\mathrm{Fe}_{3} \mathrm{O}_{4}$ and $\mathrm{CS} / \mathrm{HA} / \mathrm{Fe}_{3} \mathrm{O}_{4}$ (insets: magnetic separation of $\mathrm{CS} / \mathrm{HA} / \mathrm{Fe}_{3} \mathrm{O}_{4}$ from the aqueous suspensions).

\subsection{Optimization of the related parameters}

\subsubsection{Effect of CS to HA weight ratio}

Since the role of HA in the composite was to stabilize CS and provide adsorption sites for adsorbing $\mathrm{Co}^{2+}$ released from AY220 degradation, the CS to HA weight ratio was thus firstly optimized according to the adsorption results shown in Fig.3. From Fig.3, it can be seen that the maximum adsorption for AY220 was obtained with 50\% $\mathrm{CS}$, and this may be resulted from the increasingly homogeneous encapsulation of the HA particles into the CS [28]. Therefore, the CS to HA weight ratio in the tri-phase composite was then set as 1:1 during the following experiments. 


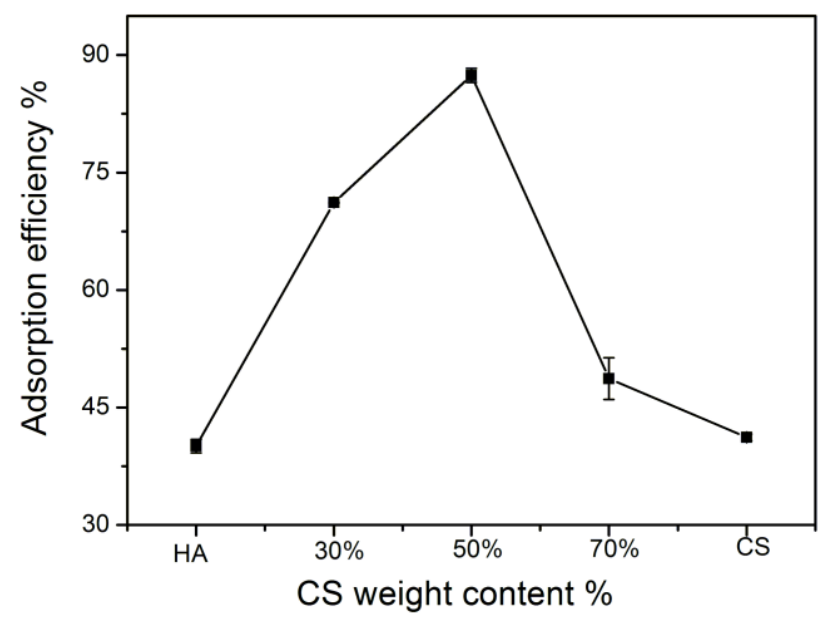

Fig.3. Effect of CS weight content in CS/HA composites on AY220 removal. Initial AY220 concentration: $500 \mathrm{mg} \mathrm{L}^{-1}$; adsorbent dosage: $30 \mathrm{mg} / 20 \mathrm{~mL}$; and treatment time: $120 \mathrm{~min}$.

\subsubsection{Effect of $\mathrm{Fe}_{3} \mathrm{O}_{4}$ weight content and $\mathrm{H}_{2} \mathrm{O}_{2}$ concentration}

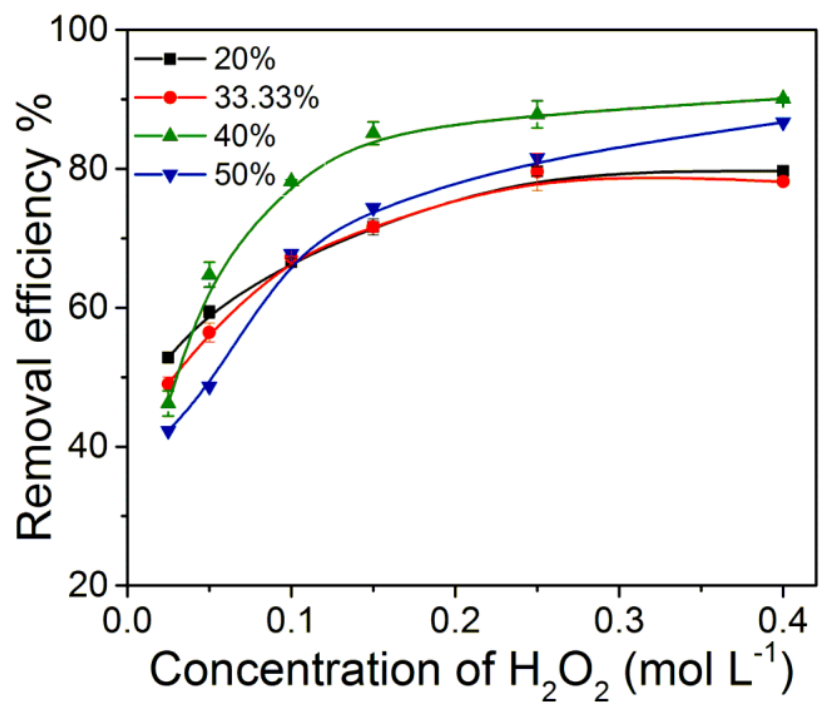

Fig.4. Effect of $\mathrm{Fe}_{3} \mathrm{O}_{4}$ weight content and $\mathrm{H}_{2} \mathrm{O}_{2}$ concentration on AY220 removal. Initial AY220 concentration: $500 \mathrm{mg} \mathrm{L}^{-1}$; adsorbent dosage: $30 \mathrm{mg} / 20 \mathrm{~mL}$; and treatment time: $120 \mathrm{~min}$.

As $\mathrm{Fe}_{3} \mathrm{O}_{4}$ is the loaded iron species on the CS/HA supporter to initiate $\mathrm{H}_{2} \mathrm{O}_{2}$ generating hydroxyl radicals (main oxidation species for degradation of AY220), the 
effects of its weight content and the $\mathrm{H}_{2} \mathrm{O}_{2}$ concentration on AY220 removal should be examined. As shown in Fig.4, it was clear that the AY220 removal efficiency increased with the $\mathrm{H}_{2} \mathrm{O}_{2}$ concentration for all CS/HA/ $/ \mathrm{Fe}_{3} \mathrm{O}_{4}$ composites with different $\mathrm{Fe}_{3} \mathrm{O}_{4}$ contents, and this was possibly caused by the increased hydroxyl radicals from increased $\mathrm{H}_{2} \mathrm{O}_{2}[29,30]$. Specifically, for $\mathrm{CS} / \mathrm{HA} / \mathrm{Fe}_{3} \mathrm{O}_{4}$ composite with $40 \% \mathrm{Fe}_{3} \mathrm{O}_{4}$ weight ratio, the dye removal efficiency increased sharply with the $\mathrm{H}_{2} \mathrm{O}_{2}$ concentration and became higher than that of all other composites with different $\mathrm{Fe}_{3} \mathrm{O}_{4}$ contents at $0.05 \mathrm{~mol} \mathrm{~L} \mathrm{~L}_{2}^{-1} \mathrm{O}_{2}$. After that, the AY220 removal efficiency continued to increase and reached a stage at $0.25 \mathrm{~mol} \mathrm{~L}^{-1}$ of $\mathrm{H}_{2} \mathrm{O}_{2}$. Herein, the $\mathrm{Fe}_{3} \mathrm{O}_{4}$ content and the $\mathrm{H}_{2} \mathrm{O}_{2}$ concentration was set at $40 \%$ and $0.25 \mathrm{~mol} \mathrm{~L}^{-1}$, respectively.

\subsubsection{Effect of $\mathrm{pH}$ and catalyst dosage}

The effect of the sample $\mathrm{pH}$ on the dye removal was determined from $\mathrm{pH} 3$ to $\mathrm{pH}$ 11 and the results were presented in Fig.5a. Although the dye removal efficiency decreased sharply from $80 \%$ to $20 \%$ when the $\mathrm{pH}$ increased from 9 to 11 , it almost retained over $80 \%$ in the $\mathrm{pH}$ range of 3-9. Compared with the classical homogenous Fenton catalyst (optimal $\mathrm{pH}$ value for reaction is about 3), using CS/HA as the supporter to load $\mathrm{Fe}_{3} \mathrm{O}_{4}$ as a heterogeneous Fenton catalyst indeed extended the $\mathrm{pH}$ range for dye removal. According to the Haber-Weiss circle, the increasing of hydroxide ions caused by the increasing of $\mathrm{pH}$ would slow down the Fenton-like reaction and produced less $\mathrm{OH}^{\bullet}$, making the dye degradation decreased and thus the removal efficiency $[20,31]$. Since the real sample $\mathrm{pH}$ was about 5 during the wool dyeing process when AY220 was used, $\mathrm{pH} 5$ was thus convenient for practical use. 

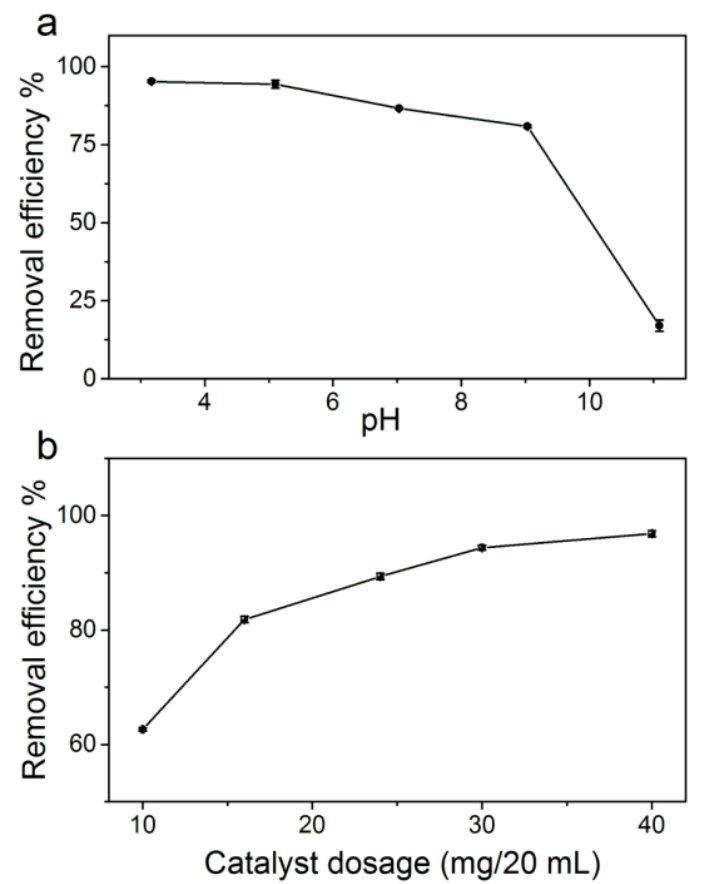

Fig.5. Effect of sample $\mathrm{pH}$ (a) and catalyst dosage (b) on AY220 removal by $\mathrm{CS} / \mathrm{HA} / \mathrm{Fe}_{3} \mathrm{O}_{4}$. Initial AY220 concentration: $500 \mathrm{mg} \mathrm{L}^{-1}$; adsorbent dosage: $30 \mathrm{mg} / 20 \mathrm{~mL}$; and treatment time: 120 min.

The influence of $\mathrm{CS} / \mathrm{HA} / \mathrm{Fe}_{3} \mathrm{O}_{4}$ dosage on the dyes removal was also investigated. As shown in Fig.5b, the removal efficiency of AY220 increased from less than $65 \%$ to over $95 \%$ with the catalyst dosage increasing from $10 \mathrm{mg} / 20 \mathrm{~mL}$ to $40 \mathrm{mg} / 20 \mathrm{~mL}$. This was due to the increasing amount of active sites for both the formation of $\bullet \mathrm{OH}$ and the adsorption of the dye [11]. The maximum removal efficiency was obtained when the dosage was $30 \mathrm{mg} / 20 \mathrm{~mL}$, which then was used in this work.

\subsection{Adsorption performance}

Because CS/HA can simultaneously provide adsorption sites for both AY220 dyes and $\mathrm{H}_{2} \mathrm{O}_{2}$, the $\mathrm{H}_{2} \mathrm{O}_{2}$ decomposition can thus be initiated to produce hydroxyl radicals 
for attacking the adsorbed dye, which then promotes the degradation of AY220. Therefore, the adsorption performance of the $\mathrm{CS} / \mathrm{HA} / \mathrm{Fe}_{3} \mathrm{O}_{4}$ should be investigated for the reason that both adsorption and catalysis coexist during the process of heterogeneous Fenton-like reaction.

\subsubsection{Adsorption kinetics}

Fig.6 shows the adsorption kinetics for AY220. It was obvious that the dye was rapidly adsorbed during the first $40 \mathrm{~min}$ and almost reached equilibrium in $160 \mathrm{~min}$. No significant changes were observed after $200 \mathrm{~min}$. The time dependence for the adsorption of $\mathrm{AY} 220$ by $\mathrm{CS} / \mathrm{HA} / \mathrm{Fe}_{3} \mathrm{O}_{4}$ composite can be well described by a pseudo-second-order model (the coefficient $\mathrm{R}^{2}$ is found to be 0.9989), which suggested that chemisorption could be the rate controlling step [32]:

$$
\frac{t}{q_{e}}=\frac{1}{k q_{e}^{2}}+\frac{t}{q_{e}}
$$

Where $\mathrm{q}_{\mathrm{e}}$ and $\mathrm{q}_{\mathrm{t}}$ is the adsorption capacity $\left(\mathrm{mg} \mathrm{g}^{-1}\right)$ at equilibrium and at time $t$ (min), respectively. $\mathrm{K}\left(\mathrm{g} \mathrm{mg}^{-1} \mathrm{~min}^{-1}\right)$ is the rate constant of pseudo-second-order adsorption. The linear plot of t/q versus $\mathrm{t}$ is shown in the inset of Fig.6.

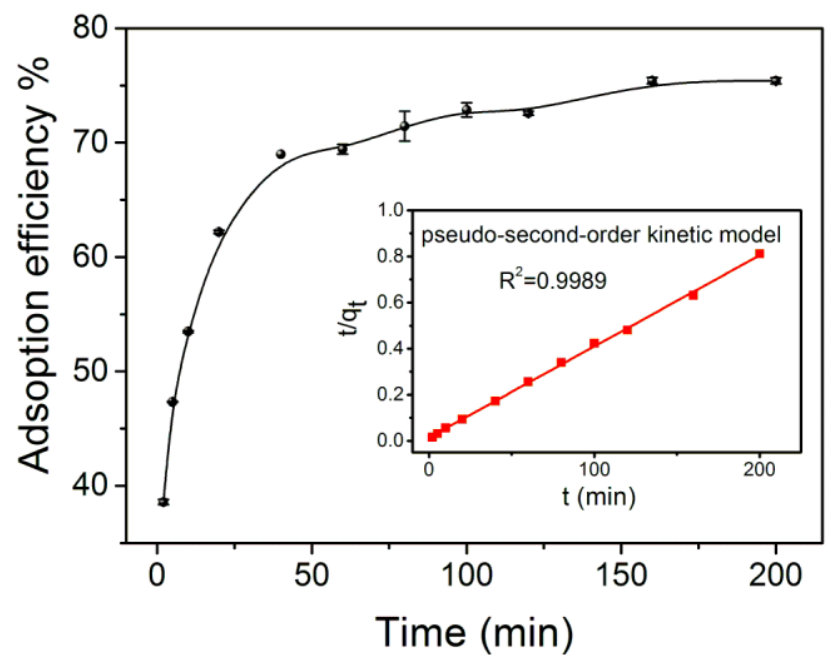


Fig.6. Adsorption kinetics for $\mathrm{AY} 220$ on $\mathrm{CS} / \mathrm{HA} / \mathrm{Fe}_{3} \mathrm{O}_{4}$ and the fitted curve (inset in Fig.5). Initial AY220 concentration: $500 \mathrm{mg} \mathrm{L}^{-1}$; adsorbent dosage: $30 \mathrm{mg} / 20 \mathrm{~mL}$; and pH value: 5 .

\subsubsection{Adsorption isotherm}

AY220 aqueous solutions with different initial concentrations from 100-1500 mg $\mathrm{L}^{-1}$ were used for the adsorption experiments. Fig.7 shows the isothermal adsorption of AY220 dye on $\mathrm{CS} / \mathrm{HA} / \mathrm{Fe}_{3} \mathrm{O}_{4}$ composite. For better understanding the adsorption patterns, Langmuir, Freundlich and Temkin equations were employed to simulate the adsorption isotherms. The Langmuir isotherm was expressed as:

$$
\frac{1}{q_{e}}=\frac{1}{q_{\max }}+\frac{1}{b q_{\max } c_{e}}
$$

where $\mathrm{Ce}$ is the equilibrium concentration of the AY220 solution $\left(\mathrm{mg} \mathrm{L}^{-1}\right), \mathrm{q}_{\max }(\mathrm{mg}$ $\left.\mathrm{g}^{-1}\right)$ and $\mathrm{b}\left(\mathrm{L} \mathrm{mg}^{-1}\right)$ is the theoretical maximum adsorption capacity and Langmuir equilibrium constants, respectively.

The Freundlich isotherm was expressed as:

$$
\ln q_{e}=\ln k_{F}+\frac{1}{n} \ln c_{e}
$$

where $\mathrm{k}_{\mathrm{F}}$ and $\mathrm{n}$ are Freundlich adsorption isotherm constants, being indicative of the extent of the adsorption. The degree of nonlinearity between $\mathrm{k}_{\mathrm{F}}$ and $(1 / \mathrm{n})$ can be determined from the linear plot of $\operatorname{lnq}_{\mathrm{e}}$ versus $\mathrm{C}_{\mathrm{e}}$.

The Temkin isotherm was presented as:

$$
q_{e}=B \ln k_{T}+B \ln c_{e}
$$

Where $\mathrm{B}$ and $\mathrm{K}_{\mathrm{T}}$ are Temkin adsorption isotherm constants, and their values can be obtained through plotting $\ln \mathrm{C}_{\mathrm{e}}$ versus $\mathrm{q}_{\mathrm{e}}$. 
The values of $\mathrm{q}_{\max }, \mathrm{b}, \mathrm{k}_{\mathrm{F}}, 1 / \mathrm{n}, \mathrm{B}, \mathrm{K}_{\mathrm{T}}$ and the correlation coefficients for the above isotherms are given in Table 2.

Table 2 Langmuir, Freundlich and Temkin parameters of removal of AY220 by $\mathrm{CS} / \mathrm{HA} / \mathrm{Fe}_{3} \mathrm{O}_{4}$

\begin{tabular}{ccccccccc}
\hline \multicolumn{3}{c}{ Langmiur model } & \multicolumn{3}{c}{ Freundich model } & \multicolumn{3}{c}{ Temkin model } \\
$\mathrm{q}_{\max }$ & $\mathrm{b}$ & $\mathrm{R}^{2}$ & $\mathrm{~K}_{\mathrm{F}}$ & $1 / \mathrm{n}$ & $\mathrm{R}^{2}$ & $\mathrm{~B}$ & $\mathrm{~K}_{\mathrm{T}}$ & $\mathrm{R}^{2}$ \\
271.0 & 10.51 & 0.9621 & 79.28 & 0.217 & 0.9704 & 43.58 & 1.956 & 0.9967 \\
\hline
\end{tabular}

Within the investigated concentration range, Temkin model was best fitted to the removal behaviour of $\mathrm{AY} 220$ by $\mathrm{CS} / \mathrm{HA} / \mathrm{Fe}_{3} \mathrm{O}_{4}$ (Temkin fitted curve was shown in the inset of Fig.7) based on the value of $\mathrm{R}^{2}$, which indicated that AY220 was adsorbed on the uneven surface of $\mathrm{CS} / \mathrm{HA} / \mathrm{Fe}_{3} \mathrm{O}_{4}$ composite with a monolayer adsorption pattern [33].

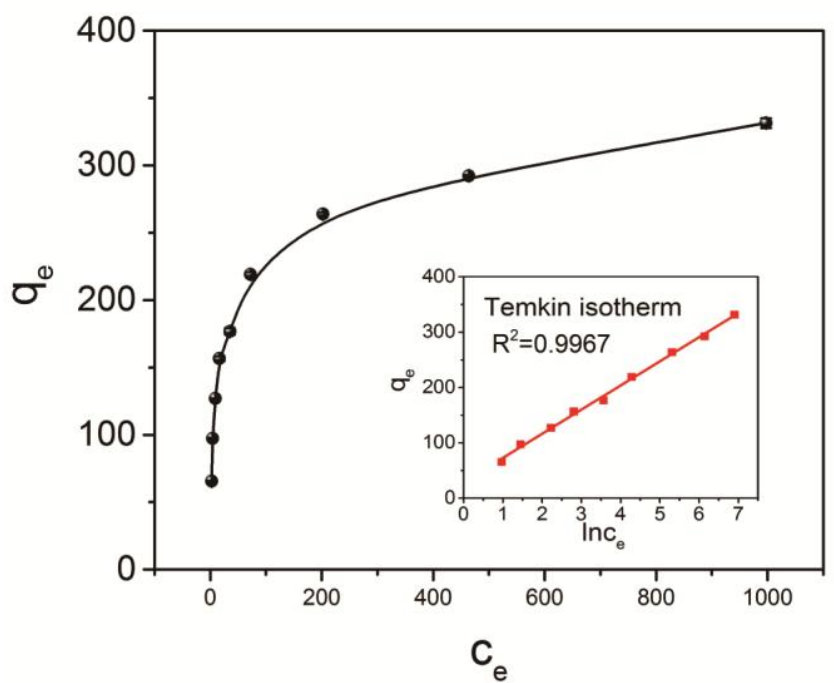

Fig.7. Adsorption isotherm for AY220 by $\mathrm{CS} / \mathrm{HA} / \mathrm{Fe}_{3} \mathrm{O}_{4}$, and Temkin fitted curve of the composite (inset in Fig.6). Adsorbent dosage: $30 \mathrm{mg} / 20 \mathrm{~mL}$ and $\mathrm{pH}$ value: 5

\subsection{Catalytic activity}




\subsubsection{Enhanced degradation efficiency by $\mathrm{CS} / \mathrm{HA} / \mathrm{Fe}_{3} \mathrm{O}_{4}$}

Fig.8 gives the catalytic degradation efficiencies of AY220 by CS/HA/Fe ${ }_{3} \mathrm{O}_{4}$ and $\mathrm{Fe}_{3} \mathrm{O}_{4}$. In comparison with bare $\mathrm{Fe}_{3} \mathrm{O}_{4}, \mathrm{CS} / \mathrm{HA} / \mathrm{Fe}_{3} \mathrm{O}_{4}$ exhibited an enhanced degradation efficiency of AY220. In fact, the enhanced degradation efficiency of $\mathrm{Fe}_{3} \mathrm{O}_{4}$ after being loaded on the supporter was also reported by $\mathrm{Hu}$ et al. [11] using nano- $\mathrm{Fe}_{3} \mathrm{O}_{4} / \mathrm{MWCNTs}$ to degrade 17 -methyltestosterone in aqueous solution. The enhanced degradation efficiency of $\mathrm{CS} / \mathrm{HA} / \mathrm{Fe}_{3} \mathrm{O}_{4}$ may relate to the increased active sites provided by a good dispersion of $\mathrm{Fe}_{3} \mathrm{O}_{4}$ on the CS/HA supporter rather than an aggregation of bare $\mathrm{Fe}_{3} \mathrm{O}_{4}$ in aqueous solution [34] (aggregation of bare $\mathrm{Fe}_{3} \mathrm{O}_{4}$ made its hydrodynamic radium bigger than that of $\mathrm{CS} / \mathrm{HA} / \mathrm{Fe}_{3} \mathrm{O}_{4}$, as shown in Fig.S1). On the other hand, $\mathrm{Co}^{2+}$ ions released during the AY220 degradation process also possibly cause the increased degradation efficiency of AY220 owing to the initiation of $\mathrm{H}_{2} \mathrm{O}_{2}$ by the absorbed $\mathrm{Co}^{2+}$, thus promoting the generation of hydroxyl radicals. Moreover, the degradation efficiency of AY220 by $\mathrm{CS} / \mathrm{HA} / \mathrm{Fe}_{3} \mathrm{O}_{4}$ was also much higher than that of the raw-CS based catalyst $\left(\mathrm{CS} / \mathrm{Fe}_{3} \mathrm{O}_{4}\right.$ composite) (Fig.S2), anf this further confirmed the combination of HA with CS indeed improved the stability of CS.

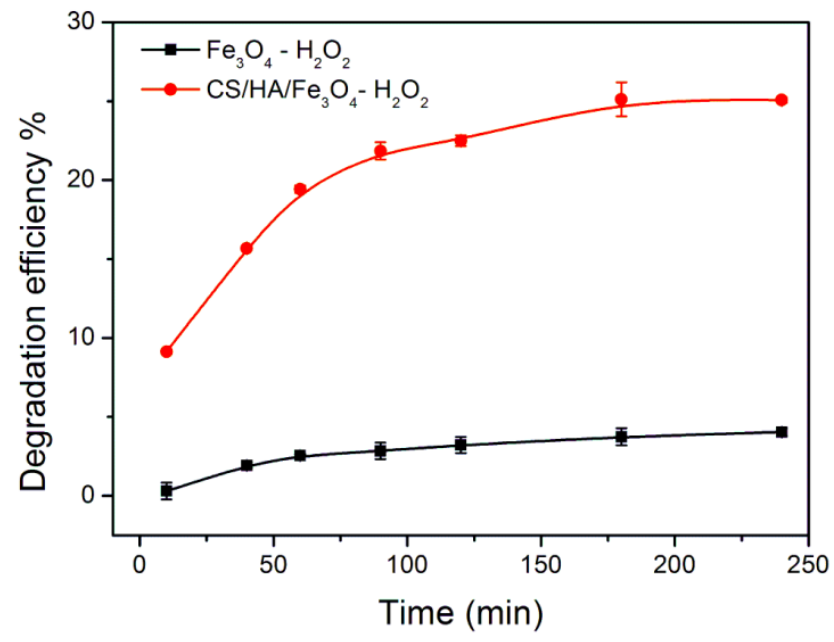


Fig.8. Enhanced degradation of $\mathrm{AY} 220$ by $\mathrm{CS} / \mathrm{HA} / \mathrm{Fe}_{3} \mathrm{O}_{4}$ compared with $\mathrm{Fe}_{3} \mathrm{O}_{4}$. Initial AY220 concentration: $500 \mathrm{mg} \mathrm{L}^{-1}$; catalysts dosage: $30 \mathrm{mg} / 20 \mathrm{~mL}$ of CS/HA/Fe $\mathrm{O}_{4}$ and 12 $\mathrm{mg} / 20 \mathrm{~mL}$ of $\mathrm{Fe}_{3} \mathrm{O}_{4} ; \mathrm{pH}$ value: 5 ; and $\mathrm{H}_{2} \mathrm{O}_{2}$ concentration: $0.25 \mathrm{~mol} \mathrm{~L}^{-1}$.

\subsubsection{Enhanced degradation efficiency by recyclable-used $\mathrm{CS} / \mathrm{HA} / \mathrm{Fe}_{3} \mathrm{O}_{4}$}

Variation of the degradation efficiency of AY220 by the catalyst with the increasing recyclable time of the catalyst was shown in Fig.9. As it can be seen from Fig.9, with the recyclable time increasing from Cycel 1 to Cycel 5, the degradation efficiency of AY220 enhanced significantly from $25.1 \%$ to $45.6 \%$, which is possibly due to the accumulation of absorbed $\mathrm{Co}^{2+}$ ions on the catalyst surface after several recycles [10] and the synergistic effect of the adsorbed $\mathrm{Co}^{2+}$ and the loaded $\mathrm{Fe}_{3} \mathrm{O}_{4}$ [12].

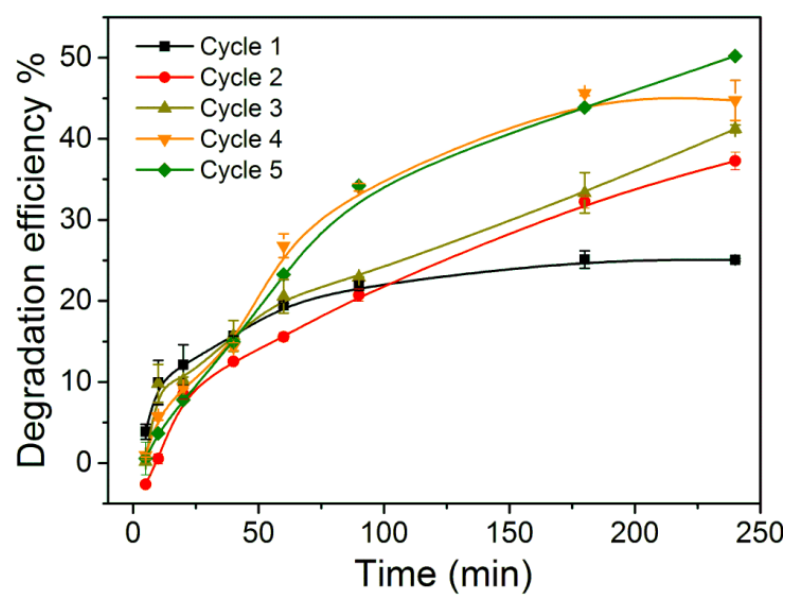

Fig.9. Variation of degradation efficiency of AY220 with the increasing recyclable time of the catalyst.

The change of the total $\mathrm{Co}^{2+}$ concentration (including chelated or free $\mathrm{Co}^{2+}$ ) in the supernatant after being treated by $\mathrm{CS} / \mathrm{HA} / \mathrm{Fe}_{3} \mathrm{O}_{4}$ in absence or presence of $\mathrm{H}_{2} \mathrm{O}_{2}$ was given in Fig.10. It was observed that the total $\mathrm{Co}^{2+}$ concentration all decreased 
with the treatment time, which indicated that AY220 can be removed efficiently by the composite no matter whether $\mathrm{H}_{2} \mathrm{O}_{2}$ is present or not. However, in the presence of $\mathrm{H}_{2} \mathrm{O}_{2}$, the total $\mathrm{Co}^{2+}$ concentration began to decrease sharply after treatment for 30 min, and decreased much lower than that without $\mathrm{H}_{2} \mathrm{O}_{2}$ after $2 \mathrm{~h}$, which implied the $\mathrm{Co}^{2+}$ released during the Fenton-like degradation may be absorbed by $\mathrm{CS} / \mathrm{HA} / \mathrm{Fe}_{3} \mathrm{O}_{4}$. Moreover, the surface $\mathrm{Co} / \mathrm{S}$ ratio of $\mathrm{CS} / \mathrm{HA} / \mathrm{Fe}_{3} \mathrm{O}_{4}$ in the presence of $\mathrm{H}_{2} \mathrm{O}_{2}$ increased from 0 to 0.71 (higher than 0.5 of AY220, determined by EDS) after dye treatment further confirmed the adsorption of $\mathrm{Co}^{2+}$ by the catalyst. Meanwhile, the surface $\mathrm{Ca} / \mathrm{P}$ ratio of $\mathrm{CS} / \mathrm{HA} / \mathrm{Fe}_{3} \mathrm{O}_{4}$ decreased from 1.63 to 1.24 after treatment implied the adsorption mainly attribute to ion exchange between $\mathrm{Ca}^{2+}$ in $\mathrm{HA}$ and $\mathrm{Co}^{2+}$ in the supernatant. The possible absorption process was illustrated in Fig.11.

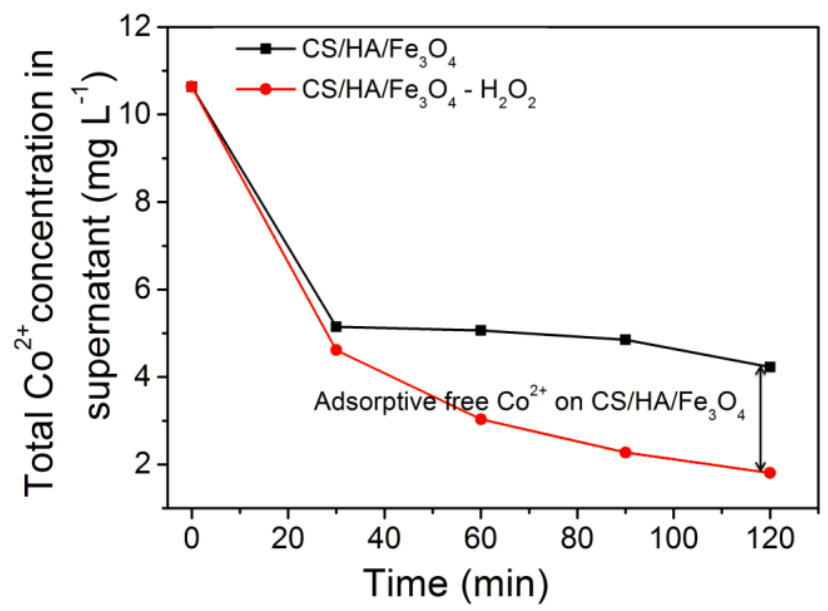

Fig.10. The total $\mathrm{Co}^{2+}$ concentration changing in the supernatant after treatment by $\mathrm{CS} / \mathrm{HA} / \mathrm{Fe}_{3} \mathrm{O}_{4}$ in absence and in presence of $\mathrm{H}_{2} \mathrm{O}_{2}$ 


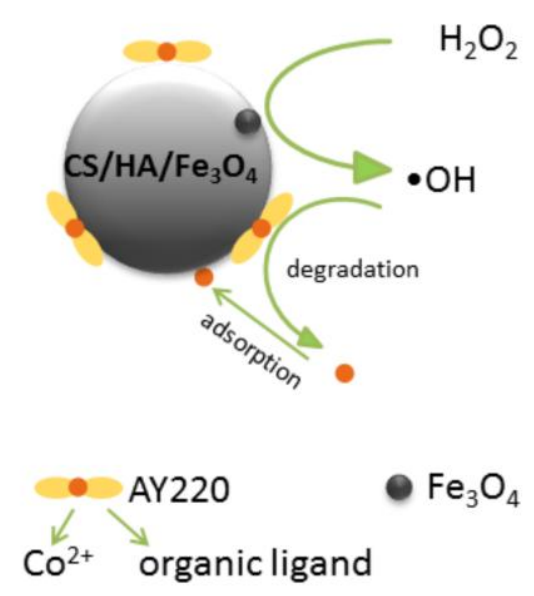

Fig.11. Scheme of the adsorption of free $\mathrm{Co}^{2+}$ released from AY220 degradation by $\mathrm{CS} / \mathrm{HA} / \mathrm{Fe}_{3} \mathrm{O}_{4}$ in the presence of $\mathrm{H}_{2} \mathrm{O}_{2}$

Furthermore, the effect of the adsorption amount for $\mathrm{Co}^{2+}$ in $\mathrm{CoCl}_{2}$ solutions by the catalyst on its degradation efficiency of AY220 was also evaluated (the adsorption amount for $\mathrm{Co}^{2+}$ and the degradation efficiency of AY220 by the catalyst after adsorbed $\mathrm{Co}^{2+}$ in $\mathrm{CoCl}_{2}$ solutions with different initial concentrations was shown in Fig.S3), and the result was shown in Fig.12. With increasing of the adsorption amount for $\mathrm{Co}^{2+}$ from 77.4 to189 $\mu \mathrm{g}$, the degradation efficiency of AY220 by the catalyst increased greatly and reached $51 \%$, and this indicated that the accumulation of free $\mathrm{Co}^{2+}$ on the catalyst surface after recyclable use was indeed directly correlated with its improved dyes degradation efficiency. 


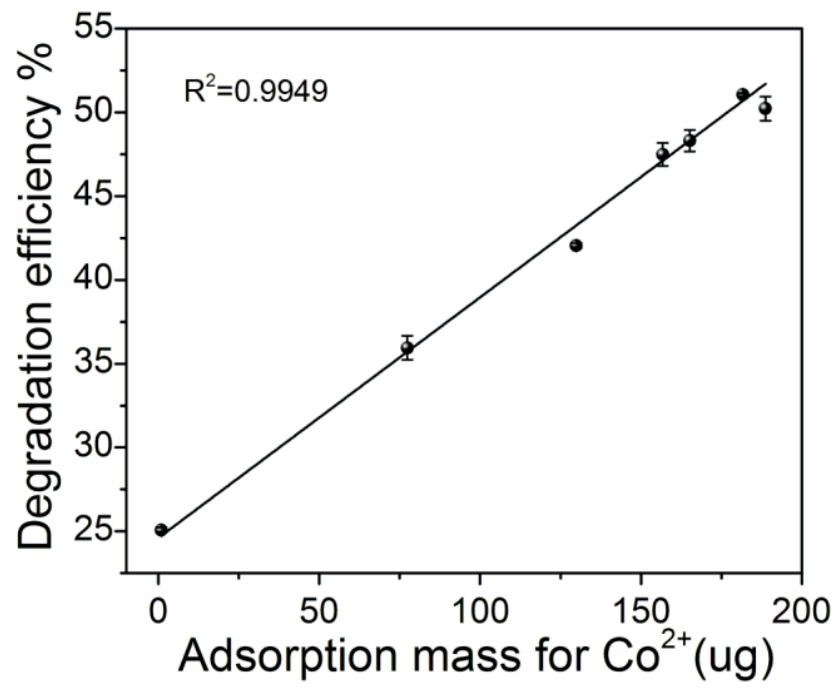

Fig.12. The effect of the adsorption amount for $\mathrm{Co}^{2+}$ by the catalyst on its degradation efficiency.

Finally, the degradation efficiency of AY220 by the $\mathrm{CS} / \mathrm{HA} / \mathrm{Fe}_{3} \mathrm{O}_{4}$ with $\mathrm{Co}^{2+}$ adsorbed on its surface and equivalent $\mathrm{Co}^{2+}$ in solution was compared. The results was given in Fig.13. The $\mathrm{CS} / \mathrm{HA} / \mathrm{Fe}_{3} \mathrm{O}_{4}$ with $\mathrm{Co}^{2+}$ showed a much higher degradation efficiency for AY220 than that without $\mathrm{Co}^{2+}$, which suggested that a synergistic effect between adsorbed $\mathrm{Co}^{2+}$ and loaded $\mathrm{Fe}_{3} \mathrm{O}_{4}$ could exist during the dye degradation. When no $\mathrm{Co}^{2+}$ was adsorbed on the catalyst, the $\mathrm{H}_{2} \mathrm{O}_{2}$ initiation mainly involved in the following two independent processes (eq 7 and eq 8):

$$
\begin{array}{r}
\mathrm{Co}_{\text {free }}^{2+}+\mathrm{H}_{2} \mathrm{O}_{2}+\mathrm{H}^{+} \rightarrow \mathrm{Co}_{\text {free }}^{3+}+\bullet \mathrm{OH}+\mathrm{H}_{2} \mathrm{O} \\
\mathrm{Fe}^{2+}+\mathrm{H}_{2} \mathrm{O}_{2}+\mathrm{H}^{+} \rightarrow \mathrm{Fe}^{3+}+\bullet \mathrm{OH}+\mathrm{H}_{2} \mathrm{O} \\
\mathrm{Co}_{\text {sur }}^{2+}+\mathrm{H}_{2} \mathrm{O}_{2}+\mathrm{H}^{+} \rightarrow \mathrm{Co}_{\text {sur }}^{3+}+\mathrm{OH}+\mathrm{H}_{2} \mathrm{O} \\
\mathrm{Fe}^{2+}+\mathrm{Co}_{\text {sur }}^{3+} \rightarrow \mathrm{Fe}^{3+}+\mathrm{Co}_{\text {sur }}^{2+} \\
\mathrm{Fe}^{2+}+\mathrm{H}_{2} \mathrm{O}_{2}+\mathrm{H}^{+} \rightarrow \mathrm{Fe}^{3+}+\bullet \mathrm{OH}+\mathrm{H}_{2} \mathrm{O}
\end{array}
$$




$$
\begin{gathered}
\mathrm{Fe}^{3+}+\mathrm{H}_{2} \mathrm{O}_{2} \rightarrow \mathrm{Fe}^{2+}+\mathrm{HO}_{2} \bullet+\mathrm{H}^{+} \\
\mathrm{Fe}^{3+}+\mathrm{HO}_{2} \bullet \rightarrow \mathrm{Fe}^{2+}+\mathrm{O}_{2}+\mathrm{H}^{+}
\end{gathered}
$$

However, for the catalyst with $\mathrm{Co}^{2+}$ adsorbed, the hydroxyl radical generation progress is different. The adsorbed $\mathrm{Co}^{2+}\left(\mathrm{Co}^{2+}{ }_{\text {sur }}\right)$ firstly initiate $\mathrm{H}_{2} \mathrm{O}_{2}$ to generate hydroxyl radicals and $\mathrm{Co}^{3+}$ (eq 9), then $\mathrm{Fe}^{2+}$ loaded on the catalyst was oxidized by $\mathrm{Co}^{3+}$ (eq 10) due to the higher redox potential of $\mathrm{Co}^{3+} / \mathrm{Co}^{2+}(1.842 \mathrm{~V})$ than that of $\mathrm{Fe}^{3+} / \mathrm{Fe}^{2+}(0.770 \mathrm{~V})$, promoting the $\cdot \mathrm{OH}$ generation through initiation of $\mathrm{H}_{2} \mathrm{O}_{2}$ by $\mathrm{Co}^{2+}$. Meanwhile, $\mathrm{Fe}^{2+}$ and $\mathrm{Fe}^{3+}$ also react with $\mathrm{H}_{2} \mathrm{O}_{2}$ as eqs 11-13 and further accelerate the generation of $\bullet \mathrm{OH}$. Therefore, the above reaction all contribute to the much higher AY220 degradation efficiency than using the catalyst without $\mathrm{Co}^{2+}$ adsorbed, and the recyclable metal-promoted Fenton-like degradation procedure was illustrated in Fig.14. 


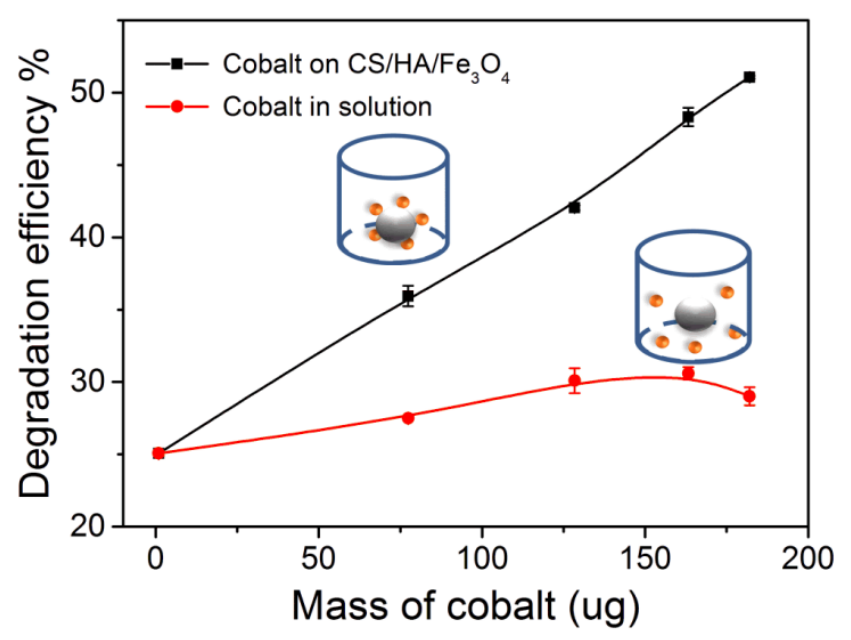

Fig.13. Degradation efficiency of $\mathrm{AY} 220$ by $\mathrm{CS} / \mathrm{HA} / \mathrm{Fe}_{3} \mathrm{O}_{4}$ with $\mathrm{Co}^{2+}$ adsorbed on its surface and in the solution under different $\mathrm{Co}^{2+}$ treatment concentration.

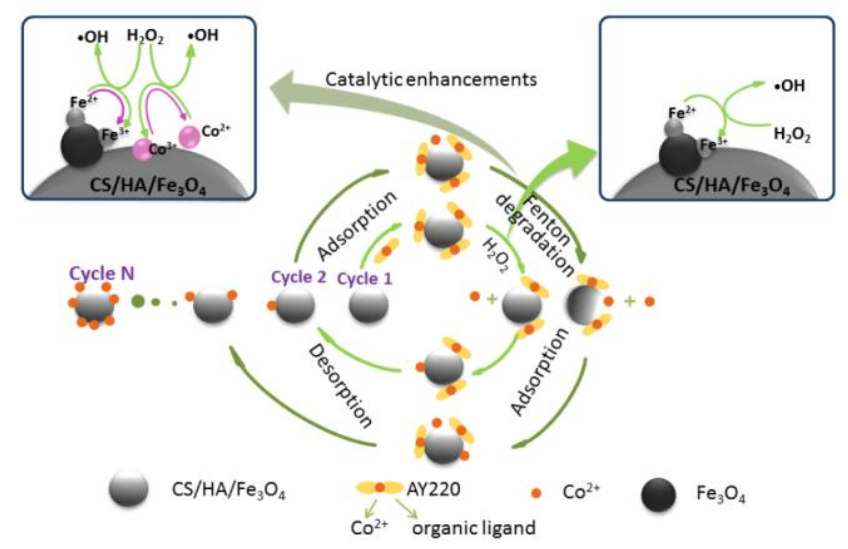

Fig.14. Schematic diagram of recyclable metal-promoted Fenton-like degradation procedure.

\subsection{The total removal efficiency of $A Y 220$ by recyclable-used $\mathrm{CS} / \mathrm{HA} / \mathrm{Fe}_{3} \mathrm{O}_{4}$}

As mentioned above that both adsorption and catalysis coexist during the process of heterogeneous Fenton-like reaction, the total removal efficiency except degradation efficiency of AY220 by recyclable-used $\mathrm{CS} / \mathrm{HA} / \mathrm{Fe}_{3} \mathrm{O}_{4}$ was also examined, and the result was given in Fig.15. It was clearly shown that the total removal efficiency of AY220 decreased from $95.0 \%$ to $80.5 \%$ after 5 runs, which indicated the adsorption 
efficiency decreased during the recyclable process. The possible reason may be ascribed to the destroyed organic phase, generated pore, and the saturated adsorption sites caused by the Fenton oxidation process [35]. However, the removal efficiency of AY220 by $\mathrm{CS} / \mathrm{HA} / \mathrm{Fe}_{3} \mathrm{O}_{4}$ still retained above $80 \%$ after 5 runs, and this implied its good recyclability for practical application.

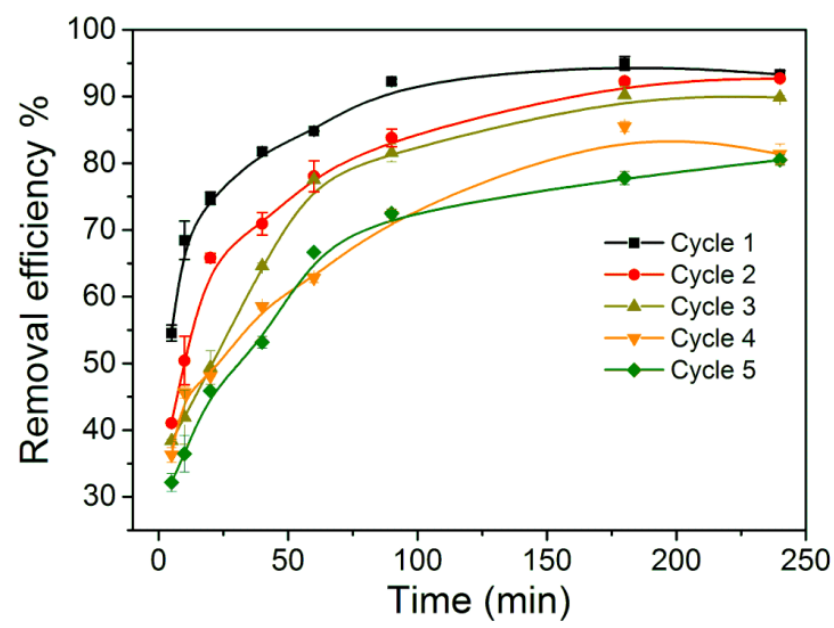

Fig.15. Total removal efficiency of AY220 by recyclable-used CS/HA/Fe $\mathrm{O}_{4}$.

\section{Conclusion}

In this work, HA instead of a cross-linking agent was introduced to combine with CS to form a dual-phase composite (CS/HA) as a supporter for $\mathrm{Fe}_{3} \mathrm{O}_{4}$ loading, and a new CS-based heterogeneous Fenton catalyst $\left(\mathrm{CS} / \mathrm{HA} / \mathrm{Fe}_{3} \mathrm{O}_{4}\right.$ magnetic composite) was thus developed for AY220 degradation/removal. The total removal efficiency of AY220 by the $\mathrm{CS} / \mathrm{HA} / \mathrm{Fe}_{3} \mathrm{O}_{4}$ magnetic composite can reach as high as $95.0 \%$. Meanwhile, it degraded AY220 without external energy and with a greatly enhanced degradation efficiency compared with the raw-CS based catalyst and bare $\mathrm{Fe}_{3} \mathrm{O}_{4}$. Moreover, it can efficiently adsorb $\mathrm{Co}^{2+}$ released from AY220 degradation, and with 
the increasing of $\mathrm{Co}^{2+}$ adsorbed on its surface after 5-time recyclable runs, its degradation efficiency of AY220 increased from $25.1 \%$ to $45.6 \%$, and this showed its recyclable metal-promoted degradation enhancement and a great potential in removal of metal complex dyes.

\section{Acknowledgements}

This work was financially supported by the Basic Research Program of Sichuan Province, China (2015JY0192) and the National Science Foundation of China (21575091). The authors also thank Professor Peng Wu of Analytical \& Testing Center, Sichuan University for his valuable comments and stimulating discussions.

\section{References}

[1] M. Adachi, T. Bredow, K. Jug, What is the origin of color on metal complex dyes? Theoretical analysis of a Ni-coordinate azo dye, Dyes Pigment., 63 (2004) 225-230.

[2] L.-N. Du, Y.-Y. Yang, G. Li, S. Wang, X.-M. Jia, Y.-H. Zhao, Optimization of heavy metal-containing dye Acid Black 172 decolorization by Pseudomonas sp DY1 using statistical designs, International Biodeterioration \& Biodegradation, 64 (2010) 566-573.

[3] T. Li, J.T. Guthrie, Colour removal from aqueous solutions of metal-complex azo dyes using bacterial cells of Shewanella strain J18 143, Bioresour. Technol., 101 (2010) 4291-4295.

[4] E. Pajootan, M. Arami, N.M. Mahmoodi, Binary system dye removal by electrocoagulation from synthetic and real colored wastewaters, J. Taiwan Inst. Chem. Eng., 43 (2012) 282-290.

[5] A. Celekli, H. Bozkurt, F. Geyik, Use of artificial neural networks and genetic algorithms for prediction of sorption of an azo-metal complex dye onto lentil straw, Bioresour. Technol., 129 (2013) 396-401.

[6] P. Blanquez, N. Casas, X. Font, X. Gabarrell, M. Sarra, G. Caminal, T. Vicent, Mechanism of textile metal dye biotransformation by Trametes versicolor, Water Res., 38 (2004) 2166-2172.

[7] Z. Aksu, E. Balibek, Effect of salinity on metal-complex dye biosorption by Rhizopus arrhizus, J. Environ. Manage., 91 (2010) 1546-1555.

[8] T. Pooja, C. Malay, Decolourisation of metal complex azo dyes and treatment of a dyehouse by modified photo-Fenton (UV-vis/ferrioxalate/H 20 2)process, Indian J. Eng. Mater. Sci., 11 (2004) 499-504.

[9] L. Gu, N.W. Zhu, H.Q. Guo, S.Q. Huang, Z.Y. Lou, H.P. Yuan, Adsorption and Fenton-like degradation 
of naphthalene dye intermediate on sewage sludge derived porous carbon, J. Hazard. Mater., 246 (2013) 145-153.

[10] S. Valizadeh, M.H. Rasoulifard, M.S.S. Dorraji, Modified Fe304- hydroxyapatite nanocomposites as heterogeneous catalysts in three UV, Vis and Fenton like degradation systems, Applied Surface Science, 319 (2014) 358-366.

[11] X.B. Hu, B.Z. Liu, Y.H. Deng, H.Z. Chen, S. Luo, C. Sun, P. Yang, S.G. Yang, Adsorption and heterogeneous Fenton degradation of 17 alpha-methyltestosterone on nano Fe304/MWCNTs in aqueous solution, Appl. Catal. B-Environ., 107 (2011) 274-283.

[12] L. Xu, J. Wang, Magnetic Nanoscaled Fe304/CeO2 Composite as an Efficient Fenton-Like Heterogeneous Catalyst for Degradation of 4-Chlorophenol, Environmental Science \& Technology, 46 (2012) 10145-10153.

[13] H. Lim, J. Lee, S. Jin, J. Kim, J. Yoon, T. Hyeon, Highly active heterogeneous Fenton catalyst using iron oxide nanoparticles immobilized in alumina coated mesoporous silica, Chemical Communications, (2006) 463-465.

[14] J.H. Ramirez, F.J. Maldonado-Hodar, A.F. Perez-Cadenas, C. Moreno-Castilla, C.A. Costa, L.M. Madeira, Azo-dye Orange II degradation by heterogeneous Fenton-like reaction using carbon-Fe catalysts, Appl. Catal. B-Environ., 75 (2007) 312-323.

[15] M.M. Cheng, W.H. Ma, J. Li, Y.P. Huang, J.C. Zhao, Visible-light-assisted degradation of dye pollutants over Fe(III)-loaded resin in the presence of $\mathrm{H} 2 \mathrm{O} 2$ at neutral $\mathrm{pH}$ values, Environmental Science \& Technology, 38 (2004) 1569-1575.

[16] Y. Lin, L. Zhang, W. Yao, H. Qian, D. Ding, W. Wu, X. Jiang, Water-Soluble Chitosan-Quantum Dot Hybrid Nanospheres toward Bioimaging and Biolabeling, Acs Applied Materials \& Interfaces, 3 (2011) 995-1002.

[17] B.K. Nandi, A. Goswami, M.K. Purkait, Adsorption characteristics of brilliant green dye on kaolin, J. Hazard. Mater., 161 (2009) 387-395.

[18] H.Y. Zhu, R. Jiang, L. Xiao, Adsorption of an anionic azo dye by chitosan/kaolin/gamma-Fe2O3 composites, Applied Clay Science, 48 (2010) 522-526.

[19] Q.Z. Huang, S.M. Wang, J.F. Huang, L.H. Zhuo, Y.C. Guo, Study on the heterogeneous degradation of chitosan with hydrogen peroxide under the catalysis of phosphotungstic acid, Carbohydr. Polym., 68 (2007) 761-765.

[20] Y. Lee, W. Lee, Degradation of trichloroethylene by Fe(II) chelated with cross-linked chitosan in a modified Fenton reaction, J. Hazard. Mater., 178 (2010) 187-193.

[21] M.S.S. Dorraji, A. Mirmohseni, M. Carraro, S. Gross, S. Simone, F. Tasselli, A. Figoli, Fenton-like catalytic activity of wet-spun chitosan hollow fibers loaded with Fe3O4 nanoparticles: Batch and continuous flow investigations, Journal of Molecular Catalysis a-Chemical, 398 (2015) 353-357.

[22] L. Wang, A.Q. Wang, Adsorption behaviors of Congo red on the N,O-carboxymethyl- chitosan/ montmorillonite nanocomposite, Chem. Eng. J., 143 (2008) 43-50.

[23] S. Chatterjee, M.W. Lee, S.H. Woo, Adsorption of congo red by chitosan hydrogel beads impregnated with carbon nanotubes, Bioresour. Technol., 101 (2010) 1800-1806.

[24] H.J. Hou, R.H. Zhou, P. Wu, L. Wu, Removal of Congo red dye from aqueous solution with hydroxyapatite/chitosan composite, Chem. Eng. J., 211 (2012) 336-342.

[25] S. Saber-Samandari, S. Saber-Samandari, N. Nezafati, K. Yahya, Efficient removal of lead (II) ions and methylene blue from aqueous solution using chitosan/Fe-hydroxyapatite nanocomposite beads, J. Environ. Manage., 146 (2014) 481-490. 
[26] X.M. Cheng, Y.B. Li, Y. Zuo, L. Zhang, J.D. Li, H.A. Wang, Properties and in vitro biological evaluation of nano-hydroxyapatite/chitosan membranes for bone guided regeneration, Materials Science \& Engineering C-Biomimetic and Supramolecular Systems, 29 (2009) 29-35.

[27] H. Jiang, Y. Zuo, L. Cheng, H.L. Wang, A.Q. Gu, Y.B. Li, A homogenous CS/NaCMC/n-HA polyelectrolyte complex membrane prepared by gradual electrostatic assembling, Journal of Materials Science-Materials in Medicine, 22 (2011) 289-297.

[28] L. Zhang, Y.B. Li, A.P. Yang, X.L. Peng, X.J. Wang, X. Zhang, Preparation and in vitro investigation of chitosan/nano-hydroxyapatite composite used as bone substitute materials, Journal of Materials Science-Materials in Medicine, 16 (2005) 213-219.

[29] N. Masomboon, C. Ratanatamskul, M.C. Lu, Chemical oxidation of 2,6-dimethylaniline by electrochemically generated Fenton's reagent, J. Hazard. Mater., 176 (2010) 92-98.

[30] Y.P. Zhao, H.Y. Hu, Photo-Fenton degradation of 17 beta-estradiol in presence of alpha-FeOOHR and H2O2, Appl. Catal. B-Environ., 78 (2008) 250-258.

[31] G.Q. Zhang, S. Wang, F.L. Yang, Efficient Adsorption and Combined Heterogeneous/Homogeneous Fenton Oxidation of Amaranth Using Supported Nano-FeOOH As Cathodic Catalysts, Journal of Physical Chemistry C, 116 (2012) 3623-3634.

[32] G. Crini, H.N. Peindy, F. Gimbert, C. Robert, Removal of Cl Basic Green 4 (Malachite Green) from aqueous solutions by adsorption using cyclodextrin-based adsorbent: Kinetic and equilibrium studies, Separation and Purification Technology, 53 (2007) 97-110.

[33] C.J. Pursell, H. Hartshorn, T. Ward, B.D. Chandler, F. Boccuzzi, Application of the Temkin Model to the Adsorption of CO on Gold, Journal of Physical Chemistry C, 115 (2011) 23880-23892.

[34] J.H. Deng, X.H. Wen, Q.N.A. Wang, Solvothermal in situ synthesis of Fe304-multi-walled carbon nanotubes with enhanced heterogeneous Fenton-like activity, Materials Research Bulletin, 47 (2012) 3369-3376.

[35] S.B. Wang, H.T. Li, S.J. Xie, S.L. Liu, L.Y. Xu, Physical and chemical regeneration of zeolitic adsorbents for dye removal in wastewater treatment, Chemosphere, 65 (2006) 82-87. 